\title{
Growth regulator and maize response to the increase in plant density
}

\author{
Lucieli Santini Leolato(1), Luis Sangoi(1), Murilo Miguel Durli(1), Fernando Panison ${ }^{(1)}$ and Ramon Voss ${ }^{(1)}$ \\ (1)Universidade do Estado de Santa Catarina (Udesc), Avenida Luiz de Camões, № 2.090, bairro Conta Dinheiro, CEP 88520-000 \\ Lages, SC, Brazil. E-mail: lucieli.leolato@gmail.com, luis.sangoi@udesc.br, murilodurli@gmail.com, fernandopanison@hotmail.com, \\ ramonez_@hotmail.com
}

\begin{abstract}
The objective of this work was to evaluate the effect of application of the growth regulator Trinexapac-ethyl on maize response to the increase in plant density at two sowing dates. A field experiment was carried out in the municipality of Lages, state of Santa Catarina, Brazil, during the 2014/2015 and 2015/2016 growing seasons. Two sowing dates (10/15 - preferential, and 12/5 - late), four plant densities (5, 7, 9, and 11 plants $\mathrm{m}^{-2}$ ), with and without Trinexapac-ethyl application, were tested. The growth regulator was sprayed at a rate of $150 \mathrm{~g}$ a.i. $\mathrm{ha}^{-1}$, when hybrid P30F53YH was at the V5 and V10 growth stages. The spraying of Trinexapac-ethyl decreased the stem length above the ear insertion node at both growing seasons. Grain yield ranged from 11,422 to $14,805 \mathrm{~kg} \mathrm{ha}^{-1}$, and increased in a quadratic way with the increment in plant density. The highest yields were reached when maize was sown in October. The spraying of Trinexapac-ethyl did not affect grain yield, but decreased the 1,000 kernels mass at both sowing dates. The use of Trinexapac-ethyl does not enhance grain yield of maize hybrid P30F53YH at crowded stands in response to the densification, regardless of sowing time.
\end{abstract}

Index terms: Zea mays, grain yield, Trinexapac-ethyl.

\section{Regulador de crescimento e resposta do milho ao aumento na densidade de plantas}

Resumo - O objetivo deste trabalho foi avaliar o efeito da aplicação do regulador de crescimento Trinexapacetil na resposta produtiva de milho ao incremento na densidade de plantas, em duas épocas de semeadura. $\mathrm{O}$ experimento foi conduzido no Município de Lages, SC, nas safras agrícolas 2014/2015 e 2015/2016. Foram testadas duas épocas de semeadura (15/10 - preferencial e 5/12 - tardia), quatro densidades de plantas (5, 7, 9, 11 plantas $\mathrm{m}^{-2}$ ), com e sem aplicação do regulador de crescimento Trinexapac-etil. O regulador de crescimento foi aplicado a dose de 150 g i.a. ha ${ }^{-1}$, nos estádios V5 e V10 do híbrido P30F53YH. A aplicação do regulador de crescimento diminuiu o comprimento do colmo acima da inserção da espiga, nas duas safras. O rendimento de grãos variou de 11.422 a $14.805 \mathrm{~kg} \mathrm{ha}^{-1}$, aumentou de forma quadrática com a elevação da densidade e foi maior para a semeadura em outubro. A aplicação de Trinexapac-etil não afetou o rendimento, mas diminuiu a massa de 1.000 grãos nas duas épocas de semeadura. A utilização do regulador de crescimento Trinexapac-etil não aumenta o rendimento de grãos do híbrido $\mathrm{P} 30 \mathrm{~F} 53 \mathrm{YH}$ em resposta ao adensamento, independentemente da época de semeadura.

Termos de indexação: Zea mays, rendimento de grãos, Trinexapac-etil.

\section{Introduction}

The sowing density is the way of manipulating plant arrangement that has the highest impact on maize productivity because small changes in population can substantially alter final yield (Piana et al., 2008). This happens because maize, differently from other species of the Poaceae family, has low vegetative plasticity and limited capacity to compensate empty spaces (Brachtvogel et al., 2009). Therefore, the increase in plant density is an alternative to enhance the crop efficiency to intercept solar radiation and to improve its productivity.
However, the use of high plant densities increases light competition, stimulates apical dominance of the tassel over the ears, favors plant etiolation and reduces stem diameter. Such morphological and physiological modifications increment the percentage of lodged and broken plants. This trend is accentuated when maize is lately sown, at the end of spring, due to the reduction of the period between crop emergence and tasseling, the lower accumulation of stem stored compounds and the poor development of plant roots (Serpa et al., 2012).

The use of cultivars with small plant height can help mitigate the negative effects of crowding. Nonetheless, 
sometimes these cultivars are not available or they are not adapted to the crop growth region. Therefore, a search for alternative management practices to overcome negative consequences of high densities, such as the use of growth regulators, is needed (Zagonel \& Ferreira, 2013).

Growth regulators are synthetic compounds that can be used to reduce the undesirable longitudinal growth of plant shoot without decreasing its productivity (Rademacher, 2000). Trinexapac-ethyl is a growth regulator that inhibits the biosynthesis of gibberellins, reducing stem length and plant height. These effects were reported in maize by Fagherazzi (2015), Pricinotto et al. (2015), and Durli (2016).

The application of Trinexapac-ethyl may fulfill the expectations of maize growers who aim to enhance the crop productivity using crowded stands or sow maize late in the Spring and run the risk of having yield losses due to stem lodging and breaking. This growth regulator can also bring positive effects on plant architecture, allowing greater interception of solar radiation and, consequently, higher grain yield (Zagonel \& Fernandes, 2007).

Zagonel \& Ferreira (2013), Fagherazzi (2015), Pricinotto et al. (2015), and Durli (2016) evaluated the response of maize hybrids to the use of Trinexapacethyl growth regulator. The divergent results gathered in these papers emphasized the need of a better understanding of parameters related to the product, application method (rate and phenological stage), hybrid sensibility and effects on maize agronomic traits. The present work was based on the hypothesis that the growth regulator Trinexapac-ethyl increases the response of maize grain yield to crowding, especially at late sowing dates.

The objective of this work was to evaluate the effect of application of the growth regulator Trinexapacethyl on maize response to the increase in plant density at two sowing dates.

\section{Materials and Methods}

A field experiment was carried out in the municipality of Lages $\left(27^{\circ} 50^{\prime} 35^{\prime \prime} \mathrm{S}, 50^{\circ} 29^{\prime} 45^{\prime \prime} \mathrm{W}\right.$, at $849 \mathrm{~m}$ altitude) in the state of Santa Catarina, Brazil, during the growing seasons of 2014/2015 and 2015/2016. The soil in the experimental area was classified as a Nitossolo Vermelho distrófico típico (Santos et al., 2013), i.e., a
Rhodic Kandiudox. The soil superficial layer, from 0 to $20 \mathrm{~cm}$, presented in September of 2014 the following phisico-chemical attributes: clay content, $560 \mathrm{~g} \mathrm{~kg}^{-1}$; soil organic matter content, $60.0 \mathrm{~g} \mathrm{~kg}^{-1}$; water $\mathrm{pH}, 5.2$; pH SMP, 5.7; phosphorus, $4.4 \mathrm{mg} \mathrm{dm}^{-3}$; potassium, $186 \mathrm{mg} \mathrm{dm}^{-3}$; calcium, $5.79 \mathrm{cmolc} \mathrm{dm}^{-3}$; magnesium,

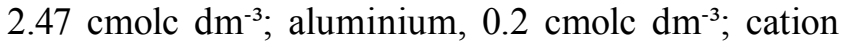
exchange capacity, $8.94 \mathrm{cmolc} \mathrm{dm}^{-3}$. The experimental area was cropped with maize monoculture during four years, following a winter coverage of black oat (Avena strigosa), which was desiccated with glyphosate herbicide in 09/14/2014 and 09/15/2015.

A randomized block design arranged in split-split plots was used, with three replicates per treatment. Two sowing dates were tested in the main plots: October 15th (preferential) and December 5th (late). Four plant densities, equivalent to $5,7,9$, and 11 plants $\mathrm{m}^{-2}$, were evaluated in the split plots. Treatments with and without the application of the growth regulator were assessed in the split-split plots. Each split-split plot comprised four rows, $0.7 \mathrm{~m}$ apart and $6 \mathrm{~m}$ long. All measurements were taken from the two central rows, totalizing a useful area of $8.4 \mathrm{~m}^{2}$, and the two outer lines were considered as border.

The experiments were hand planted in no-tillage system, using manual seeders, over a dead coverage of black oat. Three seeds of the early hybrid P30F53YH were dropped per hole. On the sowing day, $30 \mathrm{~kg} \mathrm{ha}^{-1}$ of N, $295 \mathrm{~kg} \mathrm{ha}^{-1}$ of $\mathrm{P}_{2} \mathrm{O}_{5}$ and $170 \mathrm{~kg} \mathrm{ha}^{-1}$ of $\mathrm{K}_{2} \mathrm{O}$ were applied to the soil surface, following the recommendations of the Tedesco et al. (2004) in order to reach a grain yield of $21,000 \mathrm{~kg} \mathrm{ha}^{-1}$. Urea, triple super phosphate and potassium chloride were used as $\mathrm{N}, \mathrm{P}_{2} \mathrm{O}_{5}$ and $\mathrm{K}_{2} \mathrm{O}$ sources, respectively. Nitrogen was side-dressed in three seasons when plants were at the V4, V8 and V12 growth stages, according to the scale proposed by Ritchie et al. (1993), totalizing $300 \mathrm{~kg}$ of $\mathrm{N} \mathrm{ha}^{-1}$. The trial was thinned when plants were at $\mathrm{V} 3$ to adjust plant density to the required value on each treatment. Pest insects, diseases and weeds were chemically controlled so that they did not interfere with the crop agronomic performance. The experiment was irrigated whenever soil moisture measured by tensiometers was lower than -0.40 MPa.

The growth regulator Trinexapac-ethyl was applied two times, when plants were at V5 and V10, using the commercial product Moddus, at a rate of $150 \mathrm{~g}$ a.i. in each application. The rates, growth stages and 
application amount of the growth regulator were defined according to Fagherazzi (2015). The product was pulverized over the crop top leaves with a $\mathrm{CO}_{2}$ backpack sprayer set to deliver a spray volume of $200 \mathrm{~L} \mathrm{ha}^{-1}$.

Leaf area index (LAI) was assessed at silking by the relationship between leaf area and the space occupied by one plant in each density. Plant height and ear insertion height were determined at R3 (milk grain). Length of the stem upper internodes was indirectly estimated by measuring the distance between the ear insertion node and tassel tip. Stem diameter was determined on the harvest day using a digital caliper, by sampling the middle part of the second expanded internode above the plant surface, in the smallest and largest diameter directions. All these variables were evaluated using five phenologically uniform plants that were previously tagged at V4 on each split-split plot. The percentage of lodged and broken stems was also estimated on the harvest day. Plants with stems forming an angle smaller than $45^{\circ}$ with the soil surface were considered lodged. Plants that showed stem rupture below the ear insertion node were considered broken.

Harvests were carried out on 04/11/2015 and $05 / 30 / 2015$, in the first growing season, and on $04 / 02 / 2016$ and $05 / 02 / 2016$, in the second growing season, for the sowings performed on the recommended and late date, respectively. Ears were manually harvested and shelled, and kernels were oven dried at $60^{\circ} \mathrm{C}$ until they showed a constant mass. Grain yield and its components (number of ears per plant, number of grains per ear and mass of 1,000 grains) were determined and expressed in a standard moisture of $130 \mathrm{~g} \mathrm{~kg}^{-1}$.

The data were statistically evaluated by variance analysis, using the $\mathrm{F}$ test, at the significance level of 5\% (Table 1). When $F$ values were significant, averages of the qualitative factors (sowing dates and growth regulator application) were compared using the Tukey's

Table 1. F test values, according to the variance analysis, for the variables of maize hybrid P30F53YH: ear insertion height $(\mathrm{EIH})$, plant height (PH), leaf area index (LAI), distance from the ear insertion node to tassel tip (DIS), stem diameter (SD), plants lodged and broken (PLB), number of ears per plant (NEP), number of grains per ear (NGE), mass of 1,000 grains (MTG) and grain yield (GY), as affected by the main effects of sowing date (SD), plant density (PD), growth regulator (GR) and by the interaction between these factors, during the growing seasons of 2014/2015 and 2015/2016, in the municipality of Lages, state of Santa Catarina, Brazil.

\begin{tabular}{|c|c|c|c|c|c|c|c|}
\hline Variable & $\mathrm{SD}$ & PD & GR & SDxPD & SDxGR & PDxGR & SDxPDxGR \\
\hline & \multicolumn{7}{|c|}{ 2014/2015 growing season } \\
\hline EIH & 0.41 & $4.46^{*}$ & 0.71 & 2.13 & 1.35 & 0.48 & 1.07 \\
\hline $\mathrm{PH}$ & $347.49 * *$ & 0.22 & $7.56^{*}$ & 1.42 & 2.10 & 3.01 & 1.25 \\
\hline LAI & 5.53 & $232.74 * *$ & 0.16 & 0.75 & 0.25 & 0.50 & 1.20 \\
\hline DIS & $2,078.55^{* *}$ & $6.56^{* *}$ & $11.15^{*}$ & 0.07 & 0.12 & 1.39 & 0.42 \\
\hline $\mathrm{SD}$ & 1.34 & $7.58 * *$ & $6.22 *$ & 0.64 & 0.28 & 2.10 & 1.82 \\
\hline PLB & 6.44 & 1.68 & 0.39 & 2.80 & 0.36 & 0.57 & 0.59 \\
\hline NEP & $125.87 * *$ & $61.94 * *$ & 0.02 & $4.43 *$ & 0.00 & 0.08 & 0.46 \\
\hline NGE & $87.94 * *$ & $73.20 * *$ & 0.00 & 3.11 & 0.21 & 0.14 & 0.06 \\
\hline MTG & $23.47 * *$ & $35.33 * *$ & $8.69 * *$ & 1.87 & 0.15 & 0.52 & 0.54 \\
\hline \multirow[t]{2}{*}{ GY } & $158.45^{* *}$ & $9.53 * *$ & 3.78 & 1.37 & 0.34 & 1.02 & 0.97 \\
\hline & \multicolumn{7}{|c|}{$2015 / 2016$ growing season } \\
\hline EIH & 5.40 & 1.19 & 0.02 & 1.09 & $17.00 * *$ & 0.50 & 0.27 \\
\hline $\mathrm{PH}$ & 1.92 & 1.79 & $15.75 * *$ & 2.03 & $29.61 * *$ & 0.99 & 1.33 \\
\hline LAI & 2.16 & $413.49 * *$ & 1.41 & 2.69 & 2.11 & 0.53 & 0.91 \\
\hline DIS & 0.19 & 2.17 & $33.59 * *$ & 0.99 & $7.41^{*}$ & 1.07 & 2.12 \\
\hline $\mathrm{SD}$ & $16.68 *$ & $37.77 * *$ & 2.28 & 2.14 & 3.51 & $5.96^{* *}$ & 0.91 \\
\hline PLB & 0.19 & 0.38 & 0.03 & 0.39 & 0.28 & 1.51 & 0.14 \\
\hline NEP & $29.36^{* *}$ & $33.13 * *$ & 0.17 & 3.16 & 0.00 & 0.43 & 1.83 \\
\hline NGE & $15.25^{*}$ & $50.75 * *$ & 1.59 & $6.11 * *$ & 0.02 & 0.26 & 1.04 \\
\hline MTG & 4.56 & $34.78 * *$ & $55.96 * *$ & $7.57 * *$ & 2.82 & 1.93 & 0.86 \\
\hline GY & $20.78 *$ & $17.40 * *$ & 1.96 & $8.30 * *$ & 0.41 & 0.06 & 0.67 \\
\hline
\end{tabular}

* and $* *$ Significant at 5 and $1 \%$ probability, respectively. 
test. Averages of the quantitative factor (plant density) were assessed by polynomial regression analysis. Both comparisons were conducted at the significance level of $5 \%$.

\section{Results and Discussion}

In the first growing season, plant population increase promoted a linear increment of the ear insertion height (Figure $1 \mathrm{~A}$ ). There was a difference higher than $10 \mathrm{~cm}$ for this variable between the lowest $\left(5\right.$ plants $\left.\mathrm{m}^{-2}\right)$ and the highest ( 11 plants $\mathrm{m}^{-2}$ ) plant density. In the second growing season, the growth regulator application decreased ear insertion height at the late sowing date (Table 2). Fagherazzi (2015) and Pricinotto et al. (2015) also observed reduction of ear insertion height with the application of Trinexapac-ethyl.

In $2014 / 2015$, the growth regulator reduced plant height by $6.0 \mathrm{~cm}$, based on the average of two sowing dates and four plant densities, representing a $2.2 \%$ decrease of this variable (Table 3). The plants sowed in December showed a $45 \mathrm{~cm}$ average increment of plant height, when compared to those sowed in October. In the second growing season, the pulverization of Trinexapac-ethyl diminished plant height at the late sowing date and did not affect it when maize was sown at the preferential time (Table 2). This behavior complies with the present work hypothesis, which states that the growth regulator effect on maize plant height is more pronounced in late sowing dates. The reduction of maize plant height with the use of Trinexapac-ethyl was also reported by Fagherazzi (2015), Pricinotto et al. (2015) and Durli (2016) and in other species of the Poaceae family, such as wheat (Grijalva-Contreras et al., 2012; Marco Junior et al., 2013; Chavarria et al., 2015), rice (Arf et al., 2012; Alvarez et al., 2014) and white oat (Kaspary et al., 2015).

The reduction of plant height under the influence of this growth regulator is due to the inhibition of cellular division and elongation. Trinexapac-ethyl inhibits the enzyme 3- $\beta$-hydroxylase at the end of gibberellic acid biosynthesis, dwindling the level of active acid GA1 and enhancing its precursor GA20, which has lower activity on cellular division and elongation (Davies, 2010).

In 2014/2015, the spraying of growth regulator reduced the distance between ear insertion node and tassel tip by $8 \mathrm{~cm}$, representing a $6.2 \%$ decrease in the stem upper part length (Table 3). The sowing of maize in December promoted a $47 \mathrm{~cm}$ increment in the length of this variable, in comparison to October. The increase of plant density decreased linearly the distance from ear insertion node to tassel tip (Figure $1 \mathrm{~B}$ ). In the second growing season, the distance from ear insertion node to tassel tip was smaller with the growth regulator pulverization at both sowing dates - the preferential and the late (Table 2). These results confirmed data collected by Durli (2016), who also noticed reduction of this variable with the application of Trinexapacethyl. Therefore, in maize the larger effect of this growth regulator occurs in the upper stem internodes whereas in winter cereals, such as wheat and barley, its restrictive effect is concentrated on the internodes located at the lower part of the stem (Espindula et al., 2010; Chavarria et al., 2015). Such differences in the place where Trinexapac-ethyl acts may be related to growth stage and the number of times the product is applied. In wheat, the pulverization is integrally carried out between the elongation of the $1^{\text {st }}$ and $2^{\text {nd }}$ internodes (Zagonel \& Ferreira, 2013). In the present work, Trinexapac-ethyl was applied two times, at V5 and V10.

The percentage values of lodged and broken plants were low at all treatments. They ranged from 1.1 to $7.7 \%$ and were not significantly influenced by sowing date, plant density or growth regulator application in both studied growth stages (Table 1).

In 2014/2015, the pulverization of Trinexapac-ethyl incremented the stem diameter by $0.5 \mathrm{~mm}(2.2 \%)$, regardless of sowing date (Table 3). The increase of plant density linearly reduced stem diameter of maize (Figure $1 \mathrm{C}$ ). In the second growing season, plants sowed at the recommended planting date had an average increment of $0.93 \mathrm{~mm}$ in the stem diameter, when compared to those of the late sowing date (Table 3). In 2015/2016, plant density increase also caused a linear reduction of stem diameter. However, the angular coefficient of stem diameter reduction with crowding was smaller when the growth regulator was sprayed over the canopy (Figure 2 A). Zagonel \& Ferreira (2013) and Durli (2016) also observed distinct responses of stem diameter when maize hybrids were submitted to Trinexapac-ethyl. Despite stem diameter is important to enhance plant resistance to lodging, in wheat not always the response of this variable to the 

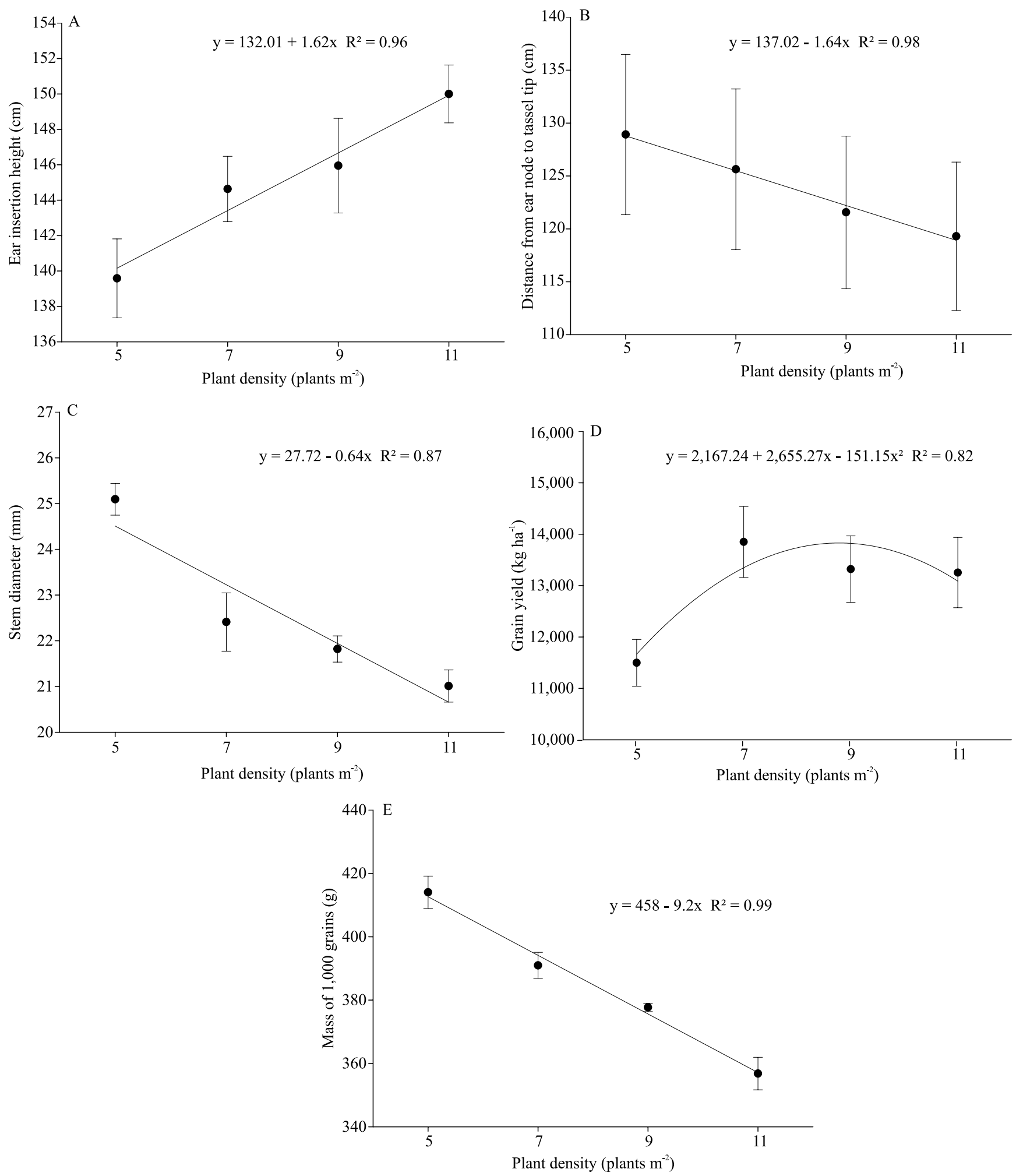

Figure 1. Ear insertion height (A), distance from the ear insertion node to tassel tip (B), stem diameter (C), grain yield (D), and mass of 1,000 grains (E) of maize hybrid P30F53YH, as affected by plant densities, on the averages of two sowing dates (10/15 and 12/05), with and without growth regulator Trinexapac-ethyl, in municipality of Lages, state of Santa Catarina, Brazil, for the 2014/2015 growing season. Each bar represents the treatment average \pm the standard error. 
application of growth regulators is detected, even in responsive cultivars (Zagonel \& Ferreira, 2013).

In the first growing season, maize sowing at the recommended planting date promoted a significant grain yield increase of $3,595 \mathrm{~kg} \mathrm{ha}^{-1}$, representing an increment of $32 \%$ when compared to the sowing performed in December, on the average of four plant densities, with and without growth regulator application (Table 3). The enhancement of plant density caused a quadratic increase of grain yield. The highest productivity was $13,828 \mathrm{~kg} \mathrm{ha}^{-1}$ and was achieved with 8.8 plants $\mathrm{m}^{-2}$ (Figure 1 D). In 2015/2016, there was also a quadratic response of grain yield to the increment in plant density (Figure 2 B). Confirming the results of the first growing season, higher yields were obtained when maize was sowed during the recommended date, in October, at all plant densities.
The highest yield values were gathered at the densities of 10.1 and 7.9 plants $\mathrm{m}^{-2}$, at the recommended and late sowing dates, which registered grain productivities of 14,805 and $13,747 \mathrm{~kg} \mathrm{ha}^{-1}$, respectively.

Figures $1 \mathrm{D}$ and $1 \mathrm{~B}$ show that grain yield response to plant density elevation above 7 plants $\mathrm{m}^{-2}$ was small, regardless of Trinexapac-ethyl application. Such behavior is probably due to the morphophysiological traits of the genotype used in the trial. P30F53YH is an early cycle hybrid that has decumbent leaves. Hiper and super early hybrids with erect leaves and short plant height are more responsive to crowding than early hybrids with flagged leaves (Strieder et al., 2008). When grown in low densities, P30F53YH has the ability to emit productive tillers which can also contribute to decrease plant density effects on grain yield (Sangoi et al., 2011).

Table 2. Ear insertion height, plant height, and distance from the ear insertion node to tassel tip (DIS) of maize hybrid $\mathrm{P} 30 \mathrm{~F} 53 \mathrm{YH}$, as affected by sowing date, with and without growth regulator Trinexapac-ethyl, on the average of four plant densities, in the municipality of Lages, state of Santa Catarina, Brazil, at the 2015/2016 growing season ${ }^{(1)}$.

\begin{tabular}{|c|c|c|c|c|c|c|}
\hline \multirow[t]{2}{*}{ Sowing date } & \multicolumn{2}{|c|}{ Ear insertion height ${ }^{(2)}(\mathrm{cm})$} & \multicolumn{2}{|c|}{ Plant height $(\mathrm{cm})$} & \multicolumn{2}{|c|}{ DIS (cm) } \\
\hline & With & Without & With & Without & With & Without \\
\hline Preferential (10/15) & $159 \mathrm{aA}$ & $151 \mathrm{aB}$ & $254 \mathrm{aA}$ & $251 \mathrm{aA}$ & $95 \mathrm{aB}$ & $100 \mathrm{aA}$ \\
\hline Late $(12 / 05)$ & $147 \mathrm{bB}$ & $154 \mathrm{aA}$ & $239 \mathrm{bB}$ & $260 \mathrm{aA}$ & $91 \mathrm{aB}$ & $105 \mathrm{aA}$ \\
\hline Coefficient of variation (\%) & \multicolumn{2}{|c|}{4.29} & \multicolumn{2}{|c|}{3.06} & \multicolumn{2}{|c|}{5.55} \\
\hline
\end{tabular}

${ }^{(1)}$ Averages followed by the same letter, lower case in the column and upper case in the row, are not significantly different by the Tukey's test at $5 \%$ probability. ${ }^{(2)}$ Variables measured at R3, according to the growth stage scale proposed by Ritchie et al. (1993).

Table 3. Plant height, distance from the ear insertion node to tassel tip (DIS), stem diameter, grain yield, and mass of 1,000 grains of maize hybrid $\mathrm{P} 30 \mathrm{~F} 53 \mathrm{YH}$, with and without growth regulator Trinexapac-ethyl, at two sowing dates, on the average of four plant densities, during the growing seasons of 2014/2015 and 2015/2016, in the municipality of Lages, state of Santa Catarina, Brazil ${ }^{(1)}$.

\begin{tabular}{|c|c|c|c|c|c|c|}
\hline \multirow[t]{2}{*}{ Variable } & \multicolumn{2}{|c|}{ Growth regulator } & \multirow{2}{*}{$\begin{array}{l}\text { Coefficient of } \\
\text { variation }(\%)\end{array}$} & \multicolumn{2}{|c|}{ Sowing date } & \multirow{2}{*}{$\begin{array}{l}\text { Coefficient of } \\
\text { variation }(\%)\end{array}$} \\
\hline & With & Without & & Preferential & Late & \\
\hline & \multicolumn{6}{|c|}{$2014 / 2015$ growing season } \\
\hline Plant height $(\mathrm{cm})^{(2)}$ & $266 b$ & $272 \mathrm{a}$ & 2.94 & $246 b$ & 291a & 3.10 \\
\hline DIS $(\mathrm{cm})^{(2)}$ & $120 \mathrm{~b}$ & $128 \mathrm{a}$ & 6.76 & $100 b$ & $147 \mathrm{a}$ & 2.84 \\
\hline Stem diameter $(\mathrm{cm})$ & $22.83 \mathrm{a}$ & $22.33 b$ & 3.13 & 22.81 & $22.36^{(3)}$ & 5.95 \\
\hline Grain yield ( $\left.\mathrm{kg} \mathrm{ha}^{-1}\right)$ & 12,696 & $13,263^{(2)}$ & 7.78 & $14,777 \mathrm{a}$ & $11,182 b$ & 7.62 \\
\hline \multirow[t]{2}{*}{ Mass of 1,000 grains $(\mathrm{g})$} & $379 b$ & $390 \mathrm{a}$ & 3.27 & $390 \mathrm{a}$ & $380 \mathrm{~b}$ & 1.89 \\
\hline & \multicolumn{6}{|c|}{$2015 / 2016$ growing season } \\
\hline Stem diameter $(\mathrm{cm})$ & 23.12 & $23.40^{(3)}$ & 2.75 & $23.73 \mathrm{a}$ & $22.80 \mathrm{~b}$ & 3.39 \\
\hline Mass of 1,000 grains $(\mathrm{g})$ & $380 \mathrm{~b}$ & $396 a$ & 1.90 & 393 & $383^{(4)}$ & 4.24 \\
\hline
\end{tabular}

${ }^{(1)}$ Averages followed by the same lower case letter in the column are not significantly different by the Tukey's test at $5 \%$ probability. ${ }^{(2)}$ Variables measured at R3, according to the growth stage scale proposed by Ritchie et al. (1993). ${ }^{(3)}$ Main effect of plant density at 5\% probability. ${ }^{(4)}$ Main effect of interaction between sowing date and plant density with and without growth regulator Trinexapac-ethyl at 5\% probability. 
Another factor that might have reduced grain yield response to the increment of plant density was the crop productivity potential. The yields recorded in the experiment were lower than $15,000 \mathrm{~kg} \mathrm{ha}^{-1}$, even with a fertilization management designed to reach $21,000 \mathrm{~kg} \mathrm{ha}^{-1}$. According to Brachtvogel et al. (2009), the higher maize potential productivity is, the greater is the grain yield response to higher plant populations.

In 2014/2015, the 1,000 grains mass was higher at the recommended than at the late sowing time, which contributed to maize greater productivity when the crop was sowed in October (Table 3). At the same growing season, the 1,000 grains mass decreased linearly with the increment of plant density (Figure $1 \mathrm{E}$ ). In $2015 / 2016$, the 1,000 grains mass diminished with crowding at both sowing dates (Figure $2 \mathrm{C}$ ) and the greater reduction rates occurred in the December sowing. Similarly to the first year, the smallest 1,000 grains mass also accounted for the lower yield of the late sowing, in comparison to the recommended planting time (Figure $2 \mathrm{~B}$ ).

The spraying of Trinexapac-ethyl reduced 1,000 grains mass at both growing seasons (Table 3). There was a significant reduction of $11 \mathrm{~g}$ in 2014/2015 and $16 \mathrm{~g}$ in 2015/2016, on the average of two sowing dates and four plant densities. Pricinotto et al. (2015) and Durli (2016) also reported reductions of maize 1,000 grains mass with the application of this growth regulator.
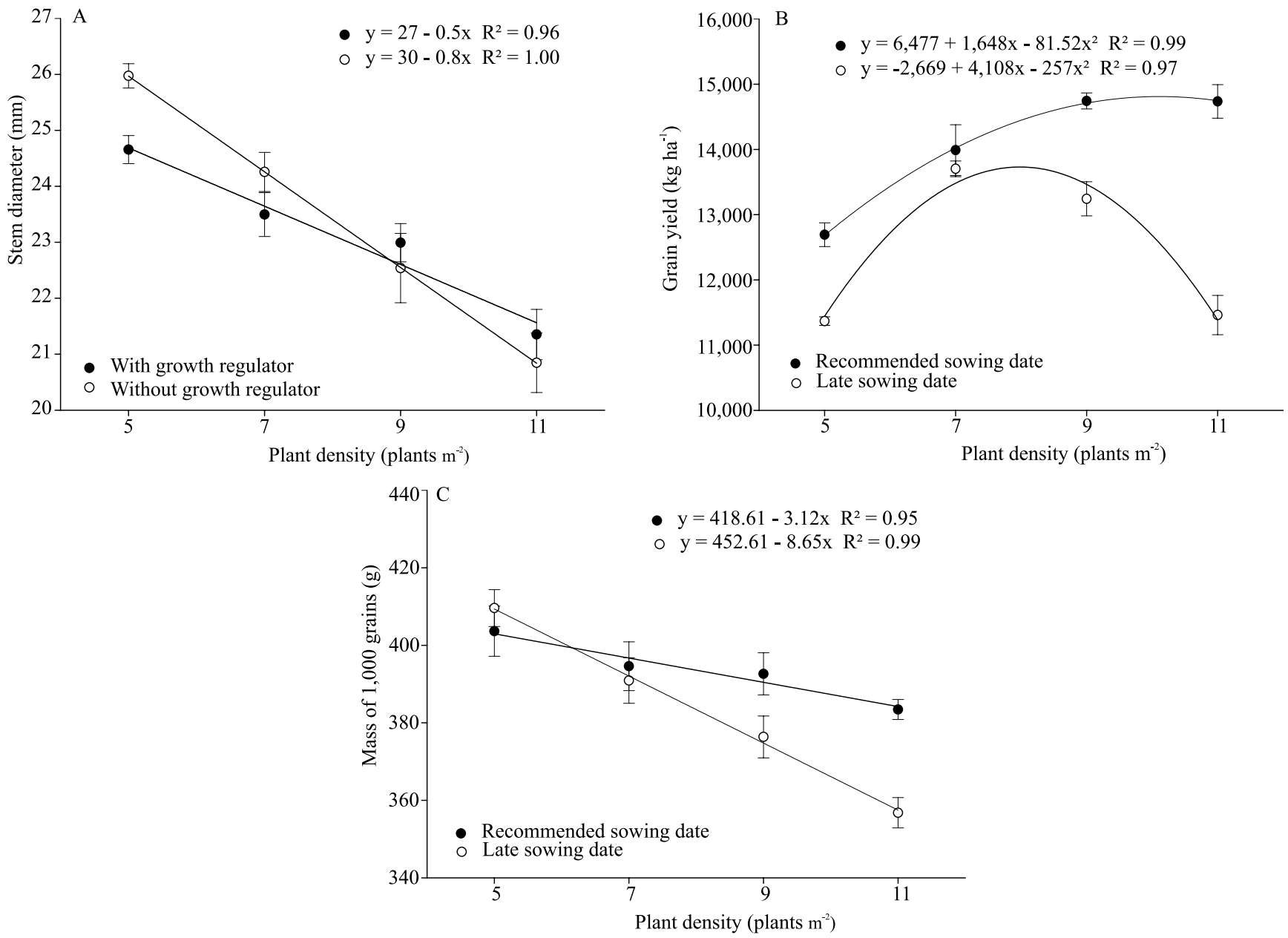

Figure 2. Stem diameter (A) as affected by the interaction between growth regulator Trinexapac-ethyl and plant density, at two sowing dates (10/15 and 12/05); grain yield (B) and mass of 1,000 grains (C) of maize hybrid P30F53YH as affected by the interaction between sowing date and plant density, with and without the growth regulator, in municipality of Lages, state of Santa Catarina, Brazil, for the 2015/2016 growing season. Each bar indicates the treatment average \pm the standard error. 
In wheat, plants with smaller height, due to application of Trinexapac-ethyl, mobilize their photosynthetic compounds to the ear, enhancing kernel mass and grain yield (Zagonel \& Fernandes, 2007). The reduction of plant height makes it feasible to increase the amount of nitrogen side-dressed to the crop, which can also help boost the winter cereals grain yield (Penckowski et al., 2010). The same pattern was not observed in the present work, since plant height reduction and canopy architecture modifications decreased 1,000 grains dry mass. It is possible that the changes on maize architecture caused by Trinexapacethyl, with the reduction of stem upper internodes, have damaged solar radiation interception of the leaves above the ear. This behavior might have reduced the production of photoassimilates during grain filling. In addition to that, shorter internodes have lower amount of stored compounds to translocate to kernels, which may also have favored the development of lighter grains (Fagherazzi, 2015).

This work was organized based on the hypothesis that the growth regulator Trinexapac-ethyl reduces plant height, mitigates stem lodging and breaking problems and increases maize grain yield response to the increment of plant density, especially at late sowing dates. This hypothesis was not confirmed under the experimental and environmental conditions in which the experiment was carried out. The low response of hybrid P30F53YH to plant density, the grain yield values below the experimental target productivities, the small percentage of lodged and broken stems and the stem upper internodes shortening promoted by this growth regulator are the main factors that probably reduced its benefits to the crop agronomic performance. Therefore, new studies assessing rates, application growth stages and hybrid kinds are necessary to evaluate the viability of using Trinexapac-ethyl as an efficient management strategy to enhance maize tolerance to crowding.

\section{Conclusions}

1. The application of Trinexapac-ethyl reduces stem length above the ear insertion node and 1,000 grains dry mass of maize hybrid $\mathrm{P} 30 \mathrm{~F} 53 \mathrm{YH}$, regardless of plant density and sowing date.

2. The growth regulator Trinexapac-ethyl does not affect grain yield response of maize hybrid P30F53YH to plant population increment, at the recommended and late sowing dates.

\section{Acknowledgments}

To Coordenação de Aperfeiçoamento de Pessoal de Nível Superior (Capes), for the scholarship granted; and to Conselho Nacional de Desenvolvimento Científico e Tecnológico ( $\mathrm{CNPq})$, for the scientific productivity fellowships granted.

\section{References}

ALVAREZ, R. de C.F.; CRUSCIOL, C.A.C.; NASCENTE, A.S. Produtividade de arroz de terras altas em função de reguladores de crescimento. Revista Ceres, v.61, p.42-49, 2014. DOI: 10.1590/ S0034-737X2014000100006.

ARF, O.; NASCIMENTO, V. do.; RODRIGUES, R.A.F.; ALVAREZ, R de C.F.; GITTI, D. d .C.; SÁ, M.E.de. Uso de etil-trinexapac em cultivares de arroz de terras altas. Pesquisa Agropecuária Tropical, v.42, p.150-158, 2012. DOI: 10.1590/ S1983-40632012000200008.

BRACHTVOGEL, E.L.; PEREIRA, F.R. da S.; CRUZ, S.C.S.; BICUDO, S.J. Densidades populacionais de milho em arranjos espaciais convencional e equidistante entre plantas. Ciência Rural, v.39, p.2334-2339, 2009. DOI: 10.1590/S010384782009005000193.

CHAVARRIA, G.; ROSA, W.P. da; HOFFMANN, L.; DURIGON, M.R. Regulador de crescimento em plantas de trigo: reflexos sobre o desenvolvimento vegetativo, rendimento e qualidade de grãos. Revista Ceres, v.62, p.583-588, 2015. DOI: 10.1590/0034737X201562060011.

DAVIES, P.J. The plant hormones: their nature, occurrence, and functions. In: DAVIES, P.J. (Ed.). Plant Hormones: biosynthesis, signal transduction, action! $3^{\text {rd }}$ ed. rev. Dordrecht: Springer, 2010. p.1-15. DOI: 10.1007/978-1-4020-2686-7_1.

DURLI, M.M. Uso do regulador de crescimento etil-trinexapac como alternativa para aumentar a resposta do milho à adubação nitrogenada em cobertura. 2016. 111p. Dissertação (Mestrado) - Universidade Estadual de Santa Catarina, Lages.

ESPINDULA, M.C.; ROCHA, V.S.; SOUZA, L.T. de.; SOUZA, M.A. de.; GROSSI, J.A.S. Efeitos de reguladores de crescimento na elongação do colmo de trigo. Acta Scientiarum. Agronomy, v.32, p.109-116, 2010. DOI: 10.4025/actasciagron.v32i1.94310.4025/ actasciagron.v32i1.943.

FAGHERAZZI, M.M. Respostas morfo-agronômicas do milho à aplicação de trinexapac-ethyl em diferentes estádios fenológicos e doses de nitrogênio. 2015. 93p. Dissertação (Mestrado) - Universidade do Estado de Santa Catarina, Lages.

GRIJALVA-CONTRERAS, R.L.; MARCÍAS-DUARTE， R.; MARTÍNEZ-DÍAZ, G.; ROBLES-CONTRERAS, F.; NUÑEZRAMÍREZ, F. Effects of Trinexapac-ethyl on different wheat 
varieties under desert conditions of Mexico. Agricultural Sciences, v.3, p.658-662, 2012. DOI: 10.4236/as.2012.35079.

KASPARY, T.E.; LAMEGO, F.P.; BELLÉ, C.; KULCZYNSKI, S.M.; PITTOL, D. Regulador de crescimento na produtividade e qualidade de sementes de aveia-branca. Planta Daninha, v.33, p.739-750, 2015. DOI: 10.1590/S0100-83582015000400012.

MARCO JUNIOR, J. de; CORREA, D.; NAKAI, E.H. Efeito do regulador de crescimento trinexapac-ethyl na produtividade de trigo. Acta Iguazu, v.2, p.14-19, 2013.

PENCKOWSKI, L.H.; ZAGONEL, J.; FERNANDES, E.C. Qualidade industrial do trigo em função do Trinexapac-ethyl e doses de nitrogênio. Ciência e Agrotecnologia, v.34, p.14921499, 2010. DOI: 10.1590/S1413-70542010000600020.

PIANA, A.T.; SILVA, P.R.F. da; BREDEMEIER, C.; SANGOI, L.; VIEIRA, V.M.; SERPA, M. da S.; JANDREY, D.B. Densidade de plantas de milho híbrido em semeadura precoce no Rio Grande do Sul. Ciência Rural, v.38, p.2608-2612, 2008. DOI: 10.1590/ S0103-84782008000900032.

PRICINOTTO, L.F.; ZUCARELI, C.; FONSECA, I.C.de B. e; OLIVEIRA, M. A. de; FERREIRA, A.S.; SPOLAOR, L.T. Trinexapac-ethyl in the vegetative and reproductive performance of corn. African Journal of Agricultural Research, v.10, p.17351742, 2015. DOI: 10.5897/AJAR2014.8613.

RADEMACHER, W. Growth retardants: effects on gibberellin biosynthesis and other metabolic pathways. Annual Review of Plant Physiology and Plant Molecular Biology, v.51, p.501-531, 2000. DOI: 10.1146/annurev.arplant.51.1.501.

RITCHIE, S.W.; HANWAY, J.J.; BENSON, G.O. How a corn plant develops. Ames: Iowa State University of Science and Technology, 1993. (Special Report, 48).
SANGOI, L.; SCHWEITZER, C.; SILVA, P.R.F. da.; SCHMITT, A.; VARGAS, V.P.; CASA, R.T.; SOUZA, C.A. de. Perfilhamento, área foliar e produtividade do milho sob diferentes arranjos espaciais. Pesquisa Agropecuária Brasileira, v.46, p.609-616, 2011. DOI: $10.1590 / \mathrm{S} 0100-204 \mathrm{X} 2011000600006$.

SANTOS, H.G. dos; JACOMINE, P.K.T.; ANJOS, L.H.C. dos; OLIVEIRA, V.A. de; LUBRERAS, J.F.; COELHO, M.R.; ALMEIDA, J.A. de; CUNHA, T.J.F.; OLIVEIRA, J.B. de. Sistema brasileiro de classificação de solos. 3.ed. rev. e ampl. Brasília: Embrapa, 2013. 353p.

SERPA, M. da S.; SILVA, P.R.F. da; SANGOI, L.; VIEIRA, V.M.; MARCHEZI, D. Densidade de plantas em híbridos de milho semeados no final do inverno em ambientes irrigados e de sequeiro. Pesquisa Agropecuária Brasileira, v.47, p.541-549, 2012. DOI: $10.1590 / \mathrm{S} 0100-204 \mathrm{X} 2012000400010$.

STRIEDER, M.L.; SILVA, P.R.F. da; RAMBO, L.; SANGOI, L.; SILVA, A.A. da; ENDRIGO, P.C. ; JANDREY, D.B. Crop management systems and maize grain yield under narrow row spacing. Scientia Agricola, v.65, p.346-353, 2008. DOI: 10.1590/ S0103-90162008000400004.

TEDESCO, M.J.; GIANELLO, C.; ANGHINONI, I.; BISSANI, C.A.; CAMARGO, F.A.O.; WIETHÖLTER, S. (Ed.). Manual de adubação e de calagem para os estados do Rio Grande do Sul e de Santa Catarina. Porto Alegre: Sociedade Brasileira de Ciência do Solo, Núcleo Regional Sul, 2004. 400p.

ZAGONEL, J.; FERNANDES, E.C. Doses e épocas de aplicação de redutor de crescimento afetando cultivares de trigo em duas doses de nitrogênio. Planta Daninha, v.25, p.331-339, 2007. DOI: 10.1590/S0100-83582007000200013.

ZAGONEL, J.; FERREIRA, C. Doses e épocas de aplicação de regulador de crescimento em híbridos de milho. Planta Daninha, v.31, p.395-402, 2013. DOI: 10.1590/S0100-83582013000200017.

Received on October 11, 2016 and accepted on February 20, 2017 